\title{
Lemorzsolódási rizikófaktorok a felvételi adatbázis alapján
}

A lemorzsolódás jelensége nem csak a hazai oktatáskutatókat érdekli, hanem számos nemzetközi szakirodalom is foglalkozik a témával Európában és a tengerentúlon egyaránt. A probléma

szinte minden országot érint, csupán a jelenség mértéke különbözó. A lemorzsolódás jelen van mind a közoktatásban, mind a felsóoktatásban. A közoktatásban a tankötelezettség korhatáráig jól nyomon követhetó a tanuló útja, ám miután elhagyja ezt az életkort, ami 2012 óta a 16. életévet jelenti (a törvény szerint), nincs az intézményeknek utánkövetési kötelezettsége, hogy mi történik a gyermekkel. A felsốoktatásban az utóbbi évtizedekben egy igen határozott törekvés jelent meg a felsóoktatás-politikai elvárásokból kiindulva annak érdekében, hogy csökkentsék a hallgatói lemorzsolódást, illetve feltárják ennek okait. Munkámban a középiskolákban és a szakgimnáziumokban végzett tanulók felsôoktatási jelenlétét és ezzel összefüggésben a lemorzsolódásukat, azok okait igyekszem feltárni.

\section{Elméleti háttér}

Demokratizálódás, expanzió, tömegesedés a felsőoktatásban

A felsőoktatás intézményrendszere sok változáson ment keresztül az évszázadok során (Hrubos, 1999), mely átalakulás a hallgatói populációt is érintette. Az oktatás demokratizálódásával szélesedett az a társadalmi réteg, aki számára elérhetővé vált az egyetemi oktatás. A megnövekedett társadalmi igények hatására tágult a felsőoktatás hálózata, bővült az intézményi kínálat, ezt nevezzük expanziónak. Ennek társadalmi oldala a tömegesedés, létszámnövekedés. A két fogalmat a kutatók ritkán választják el egymástól, hiszen nehéz az egyik hatását a másiktól megkülönböztetni (Kozma, 2004).

A 20. században bekövetkezett politikai, gazdasági és társadalmi változások következtében a felsőoktatás is megérett a változásra, fejlődésre (Ladányi, 1999). A polgári demokráciák egyik alapvető jellemzője, hogy tagjainak jogában áll az oktatás bármely szintjére lépni akaratuk és tehetségük szerint, tehát az oktatás általános emberi joggá válik. Ez azt jelenti, hogy nem csak az érettségi megszerzése válik elérhetőbbé, hanem ezzel együtt a felsőoktatásba való bekerülés is. A felsőoktatás addig csak egy szük réteg számára volt elérhető, ám a demokratizálódás hatására a társadalom egyre szélesebb köre számára nyíltak meg az egyetemek kapui (Berde, 2013; Polónyi, 2017; Ugrai, 2012; 
Veroszta, 2010) és új társadalmi csoportok jelentek meg a felsőoktatásban (Kozma, 2004; Ladányi, 1999, Polónyi, 2014).

„A második világháborút követő első felsőoktatási expanzió hatására egyes volt szocialista országok az ötvenes évek végére megelőzték hallgatói létszám tekintetében Nyugat-Európa zömét" (Csanády, 2005. 65.). Hazánkban ekkor újabb szabályozásokat vezettek be annak érdekében, hogy módosítsák a hallgatók szociális és politikai összetételét, „a munkás és szegényparaszt származású fiatalok arányának növelése volt” a cél (Ladányi, 1999. 79.).

Magyarországon az első felsőoktatási expanzió 1960-as években kezdődött, Nyugat-Európához képest jókora késéssel (Kozma, 2010; Nagy, 2003). Míg nálunk a 70-es évek középétől a 90-es évek elejéig stagnálás figyelhető meg a felsőoktatásban, addig nemzetközi szinten lezajlott az expanziós hullám második szakasza. Lemaradásunkat az is mutatja, hogy a 80-as évek közepére Nyugat-Európában a megfelelő korosztály több mint kétötöde folytatott felsőfokú tanulmányokat, Magyarországon mindössze 10-13\%át fogadta be a felsőoktatás a megfelelő korosztálynak (Gazsó, 1997). Ez Trow (1974) szerint még a felsőoktatás elit szakasza, ami addig tart, míg az aktuális korosztály kevesebb mint 15\%-a vesz részt a képzésekben. 1990-től újabb hallgatói növekedés figyelhető meg egészen 2005-ig, ami nem csak a felsőoktatásba jelentkezők és felvettek számában, hanem a felsőoktatási intézmények gyarapodásában is jelentkezett (Fábri, 2010). 1990ben a 18-22 éves népesség 9, 2004-ben már 24\%-a tanult felsőfokú intézményben (KSH, n.é.), ami már meghaladta a fentebb említett 15\%-ot, de még nem érte el a Hrubos (2014) által említett 30-35\%-ot, amit Trow (1974) alapján a tömegesedés alsó határának nevez. 2006-tól kisebb visszaesés tapasztalható összhallgatói szinten. Ha külön-külön nézzük az oktatási formákat, akkor a nappali tagozatos hallgatók számának enyhe növekedése figyelhető meg, míg az esti, levelező és távoktatásban részt vevő hallgatók aránya csökken. Az expanzió megtorpanásának oka lehetett a kiegészítő oktatási formák visszaszorulása (Kozma, 2010).

A felsőoktatási hallgatói létszám 2011-től váltott nagyobb arányú csökkenésbe (Temesi, 2016), melynek egyik oka a fiatal korosztály létszámának csökkenése vagy stagnálása, illetve a 2012-től érvénybe lépő felvételi keretszám-csökkentés és a költségtérítés helyett az önköltség bevezetése (Polónyi, 2012). Ennek kompenzálására megindult (1) a hallgatók importja elsősorban Kínából, Indiából, Koreából és Németországból; (2) a felsőoktatás diverzifikálódása (Polónyi, 2014); és (3) olyan technikainak tekinthető változtatások, mint a felvételi eljárás eltörlése és a kétszintü érettségi bevonása a felvételibe, a pontszámrendszer átalakítása stb. (Temesi, 2016).

A fentiekből jól látható, hogy a 20. századtól kezdve az expanzió következményeként fokozatosan tágult a felsőoktatásba jelentkezők társadalmi és életkori csoportja. Sáska (2014) szerint a felsőoktatásnak egyre mélyebb szintről kell meríteni az érettségizettek kínálatából. Bekerültek az etnikai kisebbséghez, a különböző vallási közösségekhez tartozók, a munkásosztályt képviselők, az idősebb korosztályhoz tartozók és a nők, akik száma egyes karokon meghaladja a férfiakét (Engler, 2017; Kozma, 2004; Pusztai, 2011). Számos hazai és nemzetközi tanulmány foglalkozik ezekkel a hallgatói csoportokkal. „A nevelésszociológiai és felsőoktatás-pedagógiai művek az e dimenziókban a korábbihoz képest új vonásokat mutató vagy társadalmi jelentőségéhez képest alulreprezentált csoportot következetesen nemtradicionális hallgatóknak nevezik" (Pusztai, 2011. 11). A nem hagyományos hallgatóknak nevezett csoport definíciója nem statikus, széles skálán mozog azoknak a köre, akiket ide tartozónak mond a szakirodalom. Nem tradicionális hallgatók a részidős képzésben részt vevők, a nem oktatás világából érkezők, az alacsony társadalmi státuszú családból érkezők, a felekezeti, vallási, kisebbségi csoporthoz tartozók, a családfenntartók, a gyermeküket egyedül nevelők, a tanulás mellett munkát vállalók és az idősebb, a 20-as éveik elejét, közepét elhagyó tanulók (Engler, 2017, Polónyi, 
2014; Pusztai, 2011), de Ausztráliában ide tartoznak az alacsony iskolai végzettségüek, a bennszülöttek és a távoli területeken élök is (Macqueen, 2017).

A nem hagyományos hallgató kifejezés azt sugallja, hogy létezik hagyományos hallgató is. Ebbe a kategóriába sorolja Macqueen (2017) azok a tanulókat, akik a közép- vagy felső társadalmi osztályból származnak és legalább az egyik szülőjük rendelkezik egyetemi végzettséggel. Európában a szakirodalom azokat a hallgatókat tekinti hagyományos hallgatóknak, akik közvetlenül az érettségi után tanulnak tovább (Engler, 2017). Magyarországon két képzési forma ad érettségi bizonyítványt, a gimnáziumok és szakgimnáziumok (a szakközépiskolák utódai 2016 szeptemberétől). Szemerszki (2014) vizsgálata arra mutat rá, hogy a két képzési forma közül nagyobb eséllyel veszik fel azokat a diákokat a felsőoktatásba, akik gimnáziumban érettségiznek. A szakközépiskolai tanulókat főként a közvetlen szakképzési előzménnyel rendelkező képzési területekre veszik fel, mint pl. az informatika, agrár, müszaki és gazdaságtudományok. Az egészségügyi képzési terület kivételt képez, mert ide a gimnáziumokból kerülnek be túlnyomó többségben. Csupán a pedagógusképzésben kiegyenlített a két képzési típusból jelentkezők aránya, 64,8\% a szakközépiskolásoké és $68,5 \%$ a gimnazisták aránya.

\section{A lemorzsolódás jelensége}

Tinto 1975-ben publikált tanulmánya szerint annak ellenére keveset tudunk a felsőoktatásban zajló lemorzsolódás természetéről, hogy széles szakirodalommal rendelkezik. Több mint negyven év után Fenyves és kollégáinak (2017) munkájában azt olvassuk, hogy ez a téma nem kap elég kutatói figyelmet, vagyis ma is érvényes Tinto fenti állítása. Bár számos vizsgálat folyt és folyik a felsőoktatást elhagyók, azok hátterének, okainak vizsgálatára, még több kutatásra van szükség ahhoz, hogy a felsőoktatási lemorzsolódás mibenlétéhez közelebb kerüljünk.

Az OECD statisztikái szerint a felsőoktatásba kerülő hallgatok 1/3-a a végzettség megszerzése nélkül hagyja el az oktatást (OECD, 2009). A lemorzsolódásnak (drop-out) többféle definíciója létezik, hiszen az egyes oktatási rendszerek sajátosságai különbözőfélék lehetnek. Az OECD oktatási statisztikája például kétféle lemorzsolódási mutatóval dolgozik, ami két korosztályhoz kötődik. Az egyik csoportba azok a 15-19 év közötti fiatalok tartoznak, akik sem az oktatási rendszerben, sem a munkaerőpiacon nincsenek jelen, míg a másik csoportba a középfokú végzettséggel nem rendelkező, oktatásból
„A nevelésszociológiai és felsóoktatás-pedagógiai múvek az e dimenziókban a korábbihoz képest új vonásokat mutató vagy társadalmi jelentóségéhez képest alulreprezentált csoportot következetesen nemtradicio(Pusztai, 2011. 11.). A nem hagyományos hallgatóknak nevezett csoport definiciója

nem statikus, széles skálán mozog azoknak a köre, akiket ide tartozónak mond a szakirodalom. Nem tradicionális hallgatók a részidôs képzésben részt vevók, a nem oktatás világából érkezók, az alacsony társadalmi státuszú családból érkezók, a felekezeti, vallási, kisebbségi csoporthoz tartozók, a családfenntartók, a gyermeküket egyedül nevelók, a tanulás mellett munkát vállalók és az idôsebb, a 20-as éveik elejét, közepét elhagyó tanulók (Engler, 2017, Polónyi, 2014; Pusztai, 2011), de Ausztráliában ide tartoznak az alacsony iskolai végzettségúek, a bennszülöttek és a távoli területeken élók is (Macqueen, 2017). nális hallgatóknak nevezik" 
kilépett 20-24 év közötti fiatalok tartoznak. Ezek alapján a nemzetközi lemorzsolódással foglalkozó mérések és módszertanok meghatározásai azt javasolják, hogy korcsoportonként kell definiálni a lemorzsolódás fogalmát (Fehérvári, 2008). Korai iskolaelhagyónak (early school leaving) nevezi a szakirodalom a középfokú végzettség illetve szakképzetség megszerzése nélkül az iskolarendszerből kikerülö diákokat. Az Európai Unió ezt a kifejezést a 18-24 év közötti fiatalokra használja (Fehérvári, 2015; Lukács és Sebö, 2015). A felsőoktatásban az intézményt, oktatást végzettség nélkül elhagyó hallgatókat tekintjük lemorzsolódóknak (Fenyves és mtsai, 2017; Molnár, 2012). Tinto (1975) különbséget tesz azon lemorzsolódó hallgatók között, akik elhagyják az intézményt, amelyben a felsőoktatási tanulmányaikat megkezdték, és egy másik intézményben folytatják a képzést, ahol végzettséget szereznek azoktól, akik az intézmény elhagyásával az egész felsőoktatási rendszerből kilépnek. Az előbbieket intézményi távozásnak, míg az utóbbit rendszertávozásnak nevezi.

Az Európai Unióhoz való csatlakozás során a kelet-közép európai országok számára feltételként fogalmazódott meg a nagy alrendszerek és intézményrendszerek, mint a felsőoktatás, sikeres felzárkózása (Csanády, 2005). Az Unió Európa 2020 stratégiájának egyik célkitüzése, hogy a 30-34 év közötti korosztályban a diplomások aránya 40\%-ra emelkedjen, hiszen egy „társadalom iskolázottsága szoros összefüggést mutat a gazdasági versenyképességgel" (Lukács és Sebő, 2015. 78.). Ennek hatására 2010-ben és 2011-ben százezer fölötti volt a jelentkezők száma, és ahogy az 1. ábrán látható is, a nappali tagozatra felvettek száma a hetvenezerhez közelített, ami az utóbbi 10 év távlatában a legmagasabb felvett hallgatói létszám volt, ugyanakkor „2013-ra mélypontra esett mind a jelentkezők, mind a felvettek létszáma” (Polónyi, 2018. 111.) tekintetében.

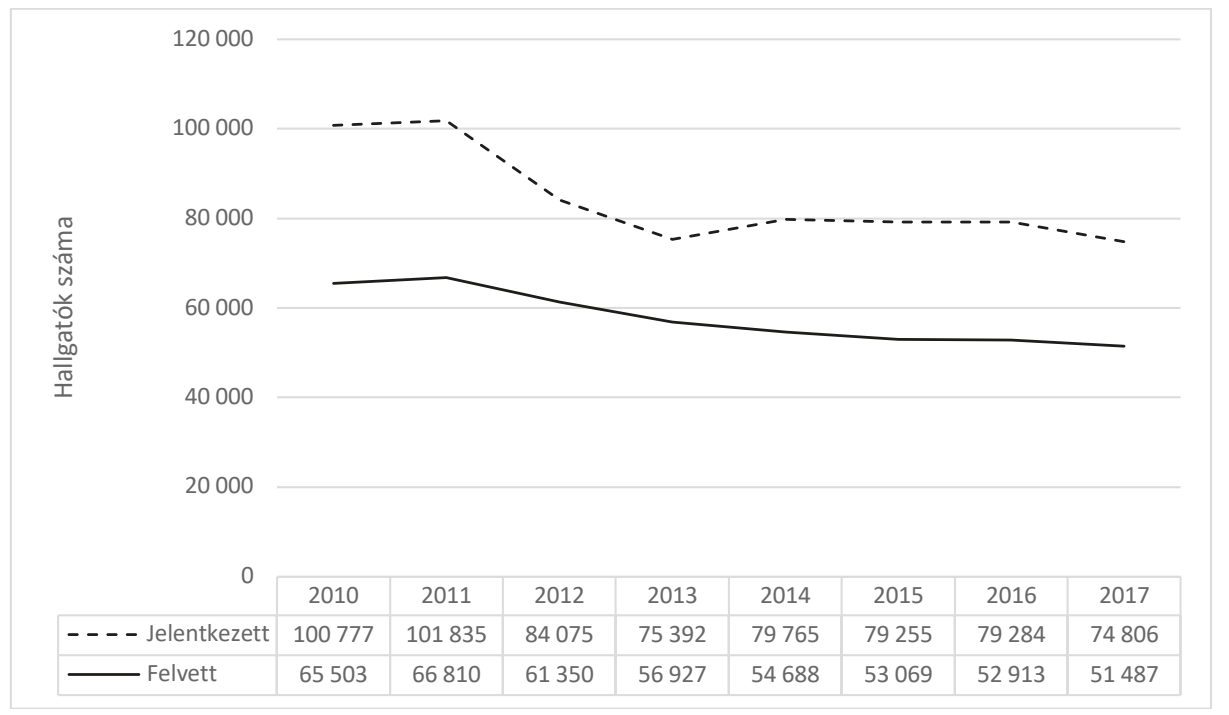

1. ábra. Nappali tagozatra jelentkezök és felvettek számának alakulása 2010-2017 között. (Forrás: KSH; saját szerkesztés)

Derényi (2015) tanulmányában kitér arra, hogy a diplomával és felsőfokú végzettséggel rendelkezők számának növelésére nem csupán a beiskolázási létszám emelésével lehet hatni, hanem a már beiskolázottak csoportjainak diplomaszerzési sikerességének javításával is. Az alacsony diplomaszerzési arányok negatív képet mutathatnak a felsőoktatási rendszerről, továbbá a gazdasági, anyagi és humán erőforrások szempontjából 
veszteséget jelent az egyén, az intézmény és az össztársadalom számára is (Fenyves és mtsai, 2017). A rendszerszinten megjelenő negatív hatások között szerepel (1) a hallgató képzésére fordított anyagi juttatások meg nem térülése pl. ösztöndíjak; (2) az állami adóbevételektől való elesés, ami az oktatásból kimaradt potenciális diplomás béréből származott volna; (3) a végzettség nélküliség alacsonyabb béreket, esetleg munkanélküliséget jelenthet, ami következtében gyakoribbak lehetnek az egészségügyi problémák, mely az államnak többletköltséget jelent az egészségügyi és szociális juttatások terén (Fenyves és mtsai, 2017; Lukács és Sebő, 2015; Tyler és Lofstrom, 2009). A felsőoktatási lemorzsolódás tehát kihat az egyén életére, az intézmény hírnevére egyaránt (Cardoso és Tavares, 2018). Ugyanakkor ne felejtsük el, hogy a lemorzsolódásnak létezik egy másik vetülete, ami a minőséggel van összefüggésben. „Nem egyértelmü ugyanis, hogy egy egyetemen azért magas a lemorzsolódási ráta, mert az oktatás színvonala alacsony, és nem teszi lehetővé a vizsgákra való felkészülést, vagy pedig azért, mert az egyetem rendkívül magas szintü »elitképzést « folytat, amely követelményeinek csak kevesen képesek megfelelni” (Polónyi, 2006. 23.).

\section{A lemorzsolódás lehetséges okai}

Az ezredforduló elött született elméleti és empirikus munkák jelentős részének fókuszában az állt, hogy magyarázatot kerestek a lemorzsolódás, a tanulmányi sikertelenség miatti bukás, a saját felsőoktatási intézményből való kiábrándulás okaira, vagyis arra, hogy egyes „,hallgatói csoportok milyen okokból nem tudják eléggé kiaknázni a kibővült felsőoktatásból adódó előnyöket” (Pusztai, 2011. 63.). Ezek közül kétségtelenül Vincent Tinto és John P. Bean munkái voltak és vannak a legnagyobb hatással a lemorzsolódással foglalkozó kutatásokra. A sokat hivatkozott Tinto (1975) által kifejlesztett elméleti modell (2. ábra) az egyén intézményben való bennmaradását vagy elhagyását határozza meg a belépési jellemzők, a hallgató céljainak és kötelezettségvállalásainak, valamint a tudományos és társadalmi intézményi tapasztalatok és integrációk alapján. Néhány évtizeddel később Tinto (1993) arra a következtetésre jutott, hogy a diákok több okból szakíthatják meg felsőoktatási tanulmányaikat, melyek között a felkészületlenség a felsőoktatási életre, a kognitív képességbeli korlátok, a motiváció, az elkötelezettség és a pénzügyi támogatás hiányát nevezte meg. Emellett kiemelte, hogy a pozitív tudományos vagy társadalmi tapasztalat kapcsolatba hozható a felsőoktatásban való bennmaradással. Cabrera, Nora és Castañeda (1993) szerint ezt az integrációs modellt empirikus bizonyítékok támasztják alá. 


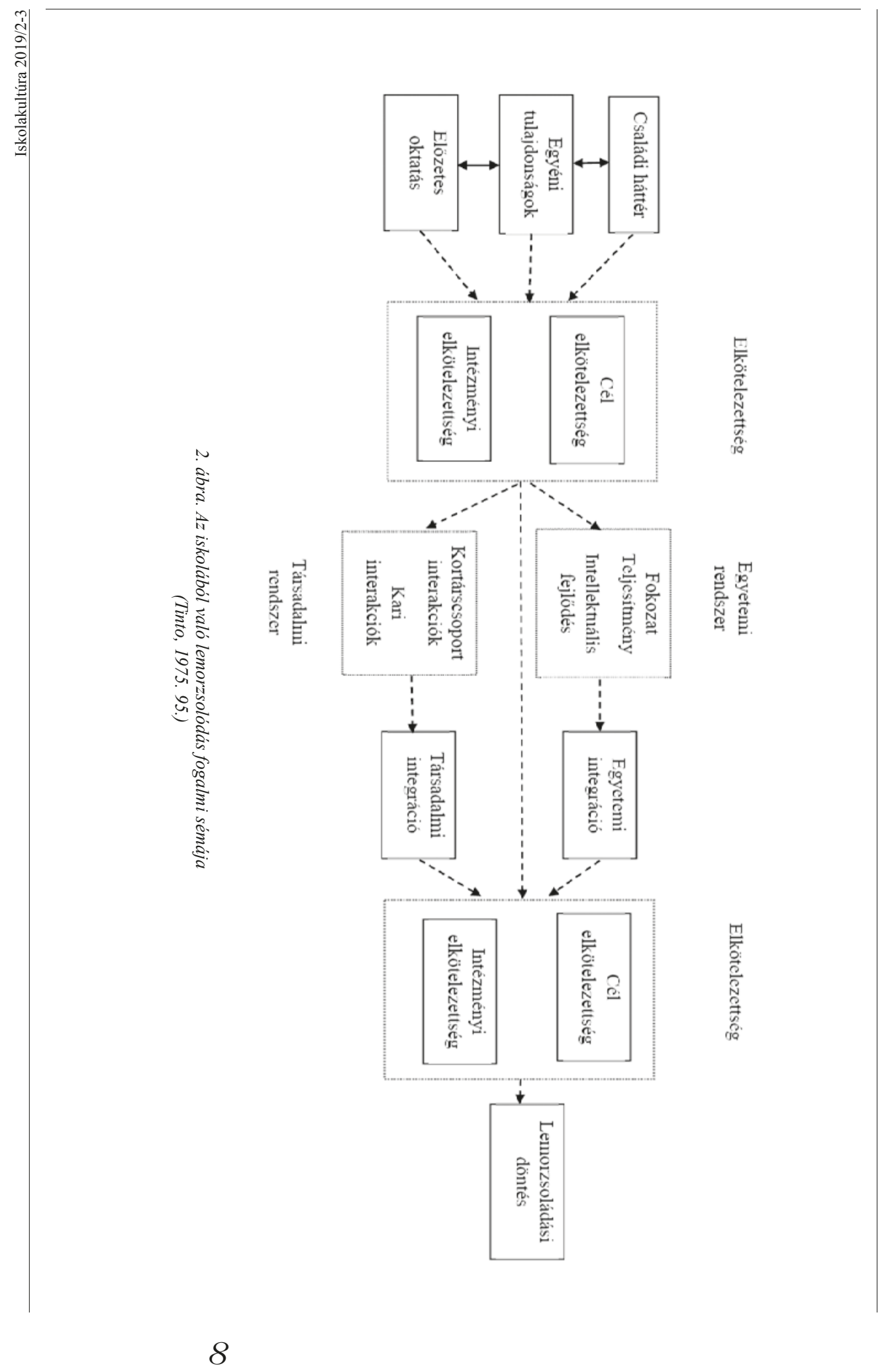


A 2. ábra alapján jól látszik, hogy Tinto az egyén háttérváltozói, az elköteleződés és integráció szintjeinek hármasára építi modelljét, amelyek befolyásolják majd a hallgató döntését abban, hogy kitart az egyetemi tanulmányok mellet vagy lemorzsolódik.

Nem csak lemorzsolódáskutatásokból tudjuk, hogy a család szocioökonómiai státusza erős befolyással bír a tanulók tanulmányi előmenetelére (Bornstein, 2015; Duncan és mtsai, 2015), az egyéni jellemzőkön belül a modellben is kiemelkedő szerepet kap a családi háttér. A belépő hallgatónak a családból magukkal hozott gazdasági és kulturális tőkéje, elsősorban a szülők iskolai végzettségének szerepe megkérdőjelezhetetlen (Pusztai, 2011). Az alacsonyabb státuszú családokból származó gyermekek magasabb lemorzsolódási arányt mutatnak, mint a magasabb státuszú családok gyermekei. Emellett fontos a szülők elvárása, támogatása, biztatása gyermekük továbbtanulásával kapcsolatosan (Fenyves és mtsai, 2017; Tinto, 1975). Az egyéni tulajdonságokon belül jelentős szerepe van a hallgatók képességének, tanuláshoz való viszonyulásuknak és ehhez kapcsolódóan az előzetes oktatási tapasztalataiknak. A modell alapján ezek a háttértényezők nagymértékben befolyásolják és elörejelzik a diákok oktatási elvárásainak, céljainak és elköteleződésének alakulását, amivel a felsőoktatási környezetbe érkeznek. A célok és az intézményi elkötelezettség szintjeinek köszönhetően tud az egyén beilleszkedni az egyetemi és társadalmi rendszerbe, ahol az interperszonális kapcsolatok, a tanulási tapasztalatok, az intellektuális fejlődés segítik a két rendszeren belüli integrációt, amelyek új elkötelezettségi szinteket eredményeznek. Minél nagyobb ez az elköteleződés, annál kisebb valószínűséggel dönt úgy a hallgató, hogy elhagyja a felsőoktatást (Tinto, 1975).

Bean $(1980 ; 1981)$ Tinto, Spady és Rootman lemorzsolódást magyarázó modelljeinek szintetizálására tett kísérletet. Négy változóosztályt azonosított, melyek a kilépési szándék legjobb előjelzői: (1) az attitűd és eredményváltozók között szerepel a bizalom, az unalom, a választás biztonsága, az oktatási célok stb. (2) A szervezeti tényezőkhöz az iskolai fokozat, a közeli barátok, a kampusz szervezeteiben való tagság, tanterv tartozik. (3) A környezeti változókon belül helyezkedik el a család figyelme, kötelezettségei, jóváhagyása, a házassági tervek stb. (4) A háttérváltozók között a szocioökonómiai státusz, a középiskolai eredmények és teljesítmény, az otthontól való távolság stb. szerepelnek.

A hallgatói lemorzsolódást vizsgáló szakirodalmak számos okot fogalmaznak meg annak magyarázatára, hogy a hallgatók miért hagyják el a felsőoktatást. Berge és Huang (2004) munkájukban négy keretrendszer mentén foglalják össze a lemorzsolódás magyarázatait: (1) a szociológiai, amelyek a különféle társadalmi erők befolyásolására összpontosítanak; (2) a szervezeti jellemzők és folyamatok; (3) a gazdasági, melyek a költség-haszon elemzéssel magyarázzák a hallgatói döntést; (4) a pszichológiai, melyek a pszichológiai jellemzők és folyamatok befolyásolására fókuszálnak. Miskolci, Bársony és Király (2018) tanulmányukban az előző keretrendszerekhez hasonlóan négy dimenzió mentén foglalták össze a lemorzsolódási magyarázatokat: (1) gazdasági okok; (2) az egyén pszichológiai, pedagógiai és tanulással kapcsolatos okai; (3) társas, kulturális hatások okai; (4) intézményi okok. Munkámban e második felosztást követve veszem számba a lemorzsolódás veszélyforrásait.

A gazdasági magyarázatok közé tartozik a hallgató és családjának anyagi helyzete. Azok a hallgatók, akiket szüleik anyagilag támogatnak, kevésbé vannak kitéve a lemorzsolódás veszélyének, hiszen nem kényszerülnek az egyetemi évek alatt dolgozni. Az anyagi nehézségek miatt dolgozni kényszerülö hallgatók egyetemi integrációja is veszélybe kerül, hiszen kevésbé tudnak bekapcsolódni az órákba és az órákon kívüli tevékenységekbe, az integráció hiánya pedig marginalizálódáshoz, elszigetelődéshez vezethet. A munkavállalás miatt egyes hallgatók félévet is halasztanak, ami tovább növeli a lemorzsolódás kockázatát (Fenyves és mtsai, 2017; Lukács és Sebő, 2015; Miskolci és mtsai, 2018; Pusztai, 2011). Emellett meg kell említeni, hogy a tanulmányokhoz és az egyetemhez kapcsolódó munkavállalás erősíti az intézményi szocializációt, továbbá 
a szakmai, gyakorlati tudás elősegíti a későbbi munkavállalást (Gáti és Róbert, 2011). A nem tradicionális hallgatók egy része is munka mellett dolgozik, ami egyrészről lemorzsolódási kockázatot jelent, másrészről ezek a hallgatók a tanulmányaik, a tanulás iránt erősebb motivációval és kiemelkedő elkötelezettséggel rendelkeznek (Engler, 2017; Miskolci és mtsai, 2018).

A gazdasági okok közé tartozik a költség-haszon elemzésen alapuló önkéntes intézményelhagyás is. Ebben az esetben a hallgató azt mérlegeli, hogy a jövője szempontjából a képzés elhagyása nagyobb haszonnal jár-e, mint annak folytatása miatt felmerülő ráfordítások (Berge és Huang, 2004; Lukács és Sebő, 2015; Miskolci és mtsai, 2018), gondoljunk csak a diploma nélkül sikeresen elhelyezkedőkre (Pusztai, 2015).

A pszichológiai tényezők közül az egyik meghatározó elem a motiváció. A motívumok magukban foglalják az olyan intrinsik tényezőket, mint például a tudás és készségek, képességek elsajátításának vágya, valamint az extrinsik motívumok közül a teljesítményorientáltságra vonatkozó tényezők, mint például a másoktól való elismerés iránti vágy. A magasabb szintü motivációval rendelkező személyek kitartóbbak, bátrabban néznek szembe a nagyobb kihívásokkal (Gilmore és mtsai, 2017), míg az alacsony motiváció könnyebben késztet a tanulmányok feladására. Csökkenhet a motivációja azoknak a hallgatóknak, akik nem abba a képzési típusba nyertek felvételt, ahová elsőként beadták jelentkezésüket. Ez magával hozhatja, hogy az egyén elvárásai nem illeszkednek a képzéssel, a tanulási környezettel, ami rontja a hallgató teljesítményét. A rossz tanulmányi eredmények és alacsony önhatékonyság gyengítik a motivációt, stresszt okozhatnak, melyek szintén hozzájárulhatnak a tanulmányok folytatásában való negatív döntéshez (Miskolci és mtsai, 2018; Raush és Hamilton, 2006). A sikertelen vagy nem elégséges tanulmányi eredmények adódhatnak a nem megfelelő tanulási stílusból. A közoktatásban elsajátított tanulási módszerek nem minden esetben alkalmasak a felsőoktatási tanulmányokra, ezért más, új tanulási módszerek elsajátítására, adaptálására kényszerítik a hallgatók. Ennek fel nem ismerése, elmulasztása vagy a korrekcióra való képesség hiánya szintén a lemorzsolódás kockázatát jelentheti (Fenyves és mtsai, 2017).

A társas és kulturális hatások közé tartozik elsösorban a család mint mikrokörnyezet és elsődleges szocializációs színtér, és a tágabb makrokörnyezet, a felsőoktatás során tapasztalt és azt megelőző intézményi és társas kapcsolatok, szerepelvárások.

A család jelentős befolyásoló szereppel rendelkezik a tanuló döntéseiben, legyen az a kitartás a tanulási célok mellett vagy az intézmény elhagyása. Ugyanilyen befolyással bír a tanuló felsőoktatásba kerülésével kapcsolatosan is: az alacsonyabb társadalmi státuszba tartozó családok gyermekei kisebb arányban lépnek magasabb oktatási szintre, és nagyobb valószínüséggel vannak kitéve a lemorzsolódás veszélyének a tanulmányi és megélhetési nehézségek vagy egyéb intézményi elvárások miatt. „A közgazdasági elméletek ezt azzal magyarázzák, hogy a hallgatók és családjuk alulbecsülik a továbbtanulás várható megtérülését, vagyis társadalmi hátterük nemcsak azáltal hat, hogy erőforrásban szegények és nem beszélik a felsőoktatás nyelvét, hanem olyan módon, hogy akár a belépéskor, akár a tanulmányok alatt (a tanulmányi intézmény, szak, tanulmányok melletti munkavállalás, intézmény helyszínére való bejárás vagy bentlakás) befolyásolja döntéseiket" (Pusztai, 2011. 75.). Azonban meg kell említeni azt is, hogy a magasabb társadalmi státuszú család gyermekei esetében előfordulhat a túlzott szülői elvárás negatív hatása a tanulóra, ami a felsőoktatás elhagyásához, lemorzsolódáshoz vezethet (Cabrera és mtsai, 2006).

A család mellett számolni kell a hallgató azon kapcsolathálójával, mely a továbbtanulás előtt és után hatással lehet rá. Ezek közé tartoznak azok a személyek, akiktől tanácsot, véleményt tud kérni döntései előtt, illetve a felsőoktatás berkein belül kialakított (tanuló) közösségek, társas kapcsolatok, amik elösegíthetik az integrációt és segíthetik az eredményes tanulást (Miskolci és mtsai, 2018; Molnár és Pintér, 2018). A nem tradicionális, 
felnőtt tanulók kapcsán gyakran felmerül a család, a tanulás és a munka összeegyeztethetetlensége. Horn (1998) longitudinális vizsgálatában arra az eredményre jutott, hogy azok maradtak ki az első év során, akiknek olyan külső kötelezettségvállalásuk volt, mint pl. a teljes munkaidős foglalkozás, a család stb. Price (2006) párkapcsolati szempontból kutatta a nem hagyományos hallgatók eredményességét. Száz tanszék bevonásával tizenegyezer fós hallgatói mintán vizsgálta a házas és nem házas hallgatók tanulmányi sikerességét. Munkájában arra mutat rá, hogy a házas hallgatók időben, jobb eredménnyel és alacsonyabb arányú lemorzsolódással végeznek egyedülálló társaiknál. Engler (2015) szerint a felnőtt korú tanulók tanulmányi eredményessége kiemelkedő, ezen belül a stabil párkapcsolatban élők és a több gyermeket nevelök bizonyulnak eredményesebbnek.

Astin (1993) szerint a hallgatók kiegyensúlyozott kapcsolata az intézménnyel sikeresebb teljesítményhez vezet. Ez egyfelöl azt jelenti, hogy a hallgató tanulási és karriercéljainak, motivációjának megfelelően választ intézményt, ami segíti, megkönnyíti egyetemi szocializációját. Ezzel szemben azok a hallgatók, akik nem oda jutottak be, ahová szerettek volna vagy bizonytalanok voltak jelentkezési szándékukban, megnehezíti ezt a beilleszkedési folyamatot, ami rizikófaktort jelent a lemorzsolódásban (Fenyves és mtsai, 2017). Amennyiben a hallgató képes beilleszkedni a felsőoktatási környezetbe, vagyis ki tudja alakítani pozitív attitüdjét mind az oktatókhoz, mind a csoporttársakhoz, képes új tanulási módszereket adaptálni és részt venni az extrakurrikuláris programokban és ki tudja aknázni az egyetemi infrastruktúrát, akkor sikeresnek mondható az egyetemi szocializációja, mely erösen csökkenti lemorzsolódási esélyeit. Másfelől a leendő hallgatók külső szempontok, mint például presztízs, elhelyezkedés stb. alapján választanak egyetemet, amiről azt gondolják, hogy leginkább megfelel az igényeiknek. Inkongruencia léphet fel, ha nem találkoznak, nem illeszkednek ezek az elvárások a tapasztalatokhoz, ami szintén oka lehet a lemorzsolódásnak (Pusztai, 2011). Bean és Metzner (1985) szerint a nem tradicionális hallgatókra kevésbé hat az intézményi légkör, ők kevésbé használják ki az intézményi infrastruktúra és az egyetemhez köthető társas kapcsolatok rendszerét, ellentétben a hagyományos hallgatókkal.
A nem tradicionális, felnôtt tanulók kapcsán gyakran felmerül a család, a tanulás és a munka összeegyeztethetetlensége. Horn (1998) longitudinális vizsgálatában arra az ered-

ményre jutott, hogy azok maradtak ki az elsó év során, akiknek olyan külsó kötelezettségvállalásuk volt, mint pl. a teljes munkaidós foglalkozás, a család stb. Price (2006) párkapcsolati szempontból kutatta a nem hagyományos hallgatók eredményességét. Száz tanszék bevonásával tizenegyezer fös hallgatói mintán vizsgálta a házas és nem házas hallgatók tanulmányi sikerességét. Munkájában arra mutat rá, hogy a házas hallgatók idóben, jobb eredménnyel és alacsonyabb arányú lemorzsolódással végeznek egyedülálló társaiknál. Engler (2015) szerint a felnótt korú tanulók tanulmányi eredményessége kiemelkedô, ezen belül a stabil párkapcsolatban élók és a több gyermeket nevelök bizonyulnak eredményesebbnek. 


\section{Az empirikus vizsgálat módszerei és eszközei}

\section{A vizsgálat célkitüzései}

Empirikus vizsgálatom középpontjában a szakgimnáziumban végzett diákok lemorzsolódási kockázatának feltérképezése áll. Azt feltételezem, hogy már a felsőoktatási intézményekbe való jelentkezés előtt és a jelentkezés beadásakor lehet lemorzsolódási rizikófaktorokat azonosítani. Vizsgálatomban a következő kérdésekre keresem a választ:

1. Milyen kockázati tényezők mutathatók ki a felsőoktatásba való jelentkezés előtt és a jelentkezés benyújtásakor?

2. Mutatkoznak-e különbségek a választott szakcsoportokban, az elért felvételi pontszámokban és egyéb bevont változók esetében a gimnáziumból és a szakgimnáziumból érkezett tanulók között?

3. Milyen mértékben befolyásolja a felvételi pontszámot a középiskola típusa, a nyelvvizsga és a szerezhető többletpontszámok?

\section{A vizsgálat mintája és módszere}

Munkámban a 2016-ban és 2017-ben érettségizett, a Dél-Alföld régió középiskoláiból általános felvételi eljárásra jelentkezett tanulóit vizsgálom. Az elemzéseket a 2016 és 2017-es felvételi adatbázisok segítségével végeztem.

A vizsgált populáció a 2016 és 2017 szeptemberében induló (a mester képzésen kívül valamennyi képzési szint és munkarend) képzésekre általános felvételi eljárásban (tehát szeptemberi kezdésre) országosan és a Dél-Alföld régióból jelentkezők és az adott évben érettségiző létszám. A vizsgálat mintáját az 1. táblázat mutatja.

1. táblázat. 2016-ban és 2017-ben felvételi eljárásra jelentkezők száma

\begin{tabular}{|lcc|cc|}
\hline & \multicolumn{2}{c|}{2016} & \multicolumn{2}{c|}{2017} \\
\cline { 2 - 5 } & Országos & Dél-Alföld régió & Országos & Dél-Alföld régió \\
\hline Összes & 111219 & 9757 & 105868 & 9012 \\
\hline Adott évben érettségizett & 41804 & 5226 & 38750 & 4698 \\
\hline
\end{tabular}

Az adatok elemzéséhez első lépésként megtisztítottam az adatbázist. Kiszürtem az olyan intézménytípusokat, mint pl. a több célú intézmények, ahol gimnáziumi és szakgimnáziumi képzést is folytatnak, mert nem volt egyértelmüen beazonosítható, hogy melyik képzési típusban érettségiztek a diákok. Bár a mintavesztés nem jelentős, mégis a kutatás korlátját jelenti.

A mintába került jelentkezők gimnázium és szakgimnázium szerinti megoszlásait a 2. ábra szemlélteti, melyen szembetünő, hogy lényegesen több a gimnáziumból való továbbtanulási szándék. 


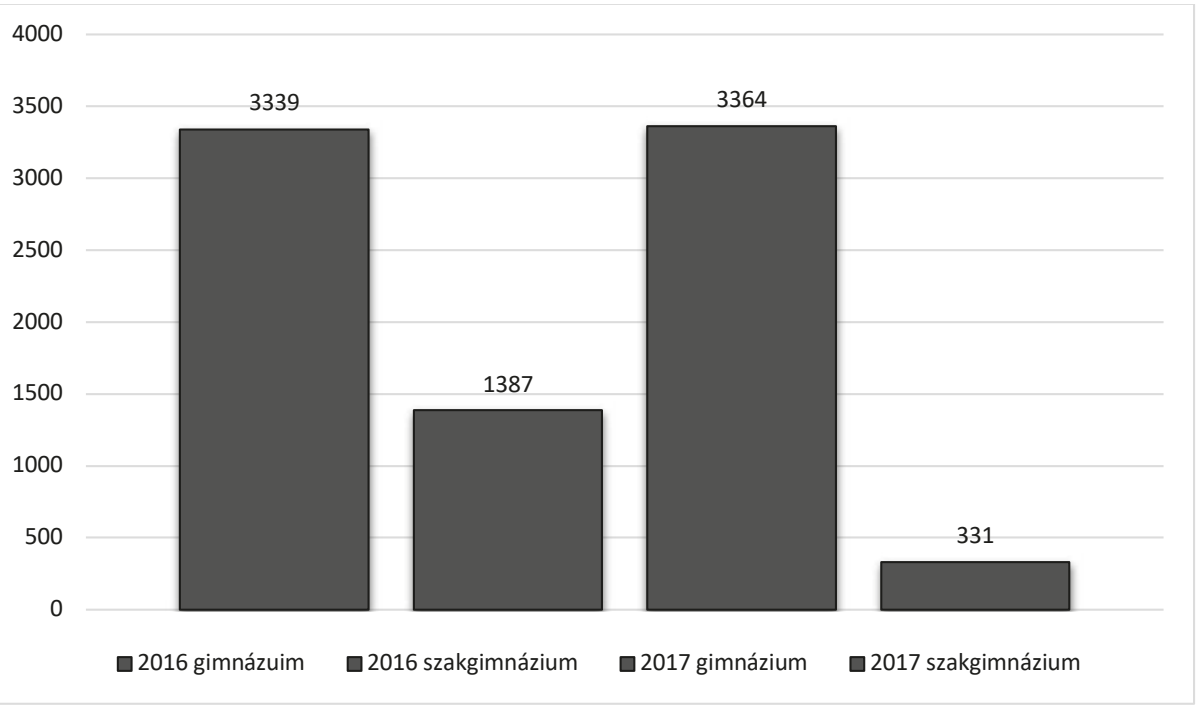

3. ábra. A vizsgálat mintájának megoszlása évenként (forrás: felvételi adatbázis; saját szerkesztés)

Mindkét részmintában a lányok vannak felülreprezentálva, 2016-ban 2006 (42\%) fiú és $2720(58 \%)$ lány szeretett volna továbbtanulni a felsőoktatásban, 2017-ben pedig 1582 (43\%) fiú és 2113 lány (57\%) jelentkezett valamelyik felsőoktatási intézménybe.

\section{Eredmények és értelmezés}

Elsőként azt néztem meg, hogy a 2016-os és 2017-es adatbázis alapján a mintába kerülők között milyen arányban vannak a gimnáziumból és szakgimnáziumból jelentkezett és felvett hallgatók aránya. 2016-ban a gimnazisták 76\%-át vették fel, a szakgimnáziumból jelentkezettek 49\%-a jutott be valamelyik felsőoktatási intézménybe. Hasonló tendenciát figyelhetünk meg 2017-ben is. A gimnáziumi diákok 79\%-a, míg a szakgimnáziumból továbbtanulók 46\%-a került be a felsőoktatásba. Az eredmények azt mutatják, hogy a középiskolai intézmény típusa befolyással van arra, hogy milyen arányban kerülnek be a hallgatók a felsőoktatásba $\left(\chi_{2016}^{2}=320,701 ; p=0,001 ; \chi^{2}{ }_{2017}=151,329 ; p=0,001\right)$.

Mivel a diploma megszerzéséhez már szükség van legalább egy középfokú nyelvvizsgára, ezért azt is megvizsgáltam, hogy milyen különbségek vannak a két részmintában a nyelvvizsgák megléte tekintetében. 2016-ban a válaszadók csupán 44\%-a ( $\mathrm{n}=4577)$, 2017-ben a minta $(n=3497)$ 55,6\%-a válaszolt a különböző típusú nyelvvizsga meglétének kérdésére, ami azt valószínüsíti, hogy a nem válaszolók nem rendelkeznek nyelvtudást igazoló okmánnyal. A 2. táblázat a két részminta nyelvvizsga-bizonyítványának számát mutatja be. 


\begin{tabular}{|c|c|c|c|c|c|c|c|c|}
\hline \multicolumn{9}{|c|}{ 2. táblázat. Nyelvvizsga-bizonyítvány száma (\%) } \\
\hline & Nyelvvizsga típusa & \multicolumn{3}{|c|}{ Gimnázium } & \multicolumn{3}{|c|}{ Szakgimgázium } & $\chi^{2}(p)$ \\
\hline & & 0 & 1 & 2 & 0 & 1 & 2 & \\
\hline \multirow{7}{*}{$\stackrel{\curvearrowright}{\stackrel{\sim}{d}}$} & Középfokú A & 70,1 & 28,6 & 1,3 & 74,5 & 25,5 & 0 & $0,892(0,640)$ \\
\hline & Középfokú B & 71,7 & 27,2 & 1,1 & 74,5 & 25,5 & 0 & $0,590(0,745)$ \\
\hline & Középfokú C & 40,7 & 54 & 5,3 & 46,8 & 53,2 & 0 & $2,927(0,231)$ \\
\hline & Felsőfokú A & 96,3 & 3,6 & 0,1 & 97,9 & 2,1 & 0 & $0,335(0,846)$ \\
\hline & Felsőfokú B & 96,3 & 3,6 & 0,1 & 100 & 0 & 0 & $1,826(0,401)$ \\
\hline & Felsőfokú C & 81,2 & 18,2 & 0,6 & 78,7 & 17 & 4,3 & $9,336(0,009)$ \\
\hline & Érettségi C & 81,9 & 18,1 & 0 & 92 & 8 & 0 & $16,941(0,001)$ \\
\hline \multirow{7}{*}{$\stackrel{0}{\stackrel{0}{d}}$} & Középfokú A & 67 & 31,9 & 1,1 & 72,7 & 26,9 & 0,4 & $4,064(0,131)$ \\
\hline & Középfokú B & 68,3 & 30,7 & 1 & 76,9 & 22,7 & 0,4 & $8,342(0,015)$ \\
\hline & Középfokú C & 43,4 & 51,8 & 4,7 & 33 & 67,7 & 0,4 & $25,853(0,001)$ \\
\hline & Felsőfokú A & 94,7 & 5,1 & 0,1 & 99,6 & 0,4 & 0 & $12,414(0,002)$ \\
\hline & Felsőfokú B & 94,5 & 5,3 & 0,1 & 99,2 & 0,3 & 0 & $10,942(0,004)$ \\
\hline & Felsőfokú C & 84 & 15,6 & 0,4 & 96,6 & 3,4 & 0 & $29,707(0,001)$ \\
\hline & Érettségi C & 83,3 & 16,7 & 0 & 93 & 7 & 0 & $71,700(0,001)$ \\
\hline
\end{tabular}

Az eredmények azt mutatják, hogy 2017-ben csak a felsőfokú C-típusú nyelvvizsga és az érettségi $C$ esetében van összefüggés az középiskola típusa és a nyelvvizsga megléte között, hiszen ha alaposabban megvizsgáljuk a táblázat ezen részét, akkor láthatjuk, hogy arányában nem rendelkeznek kevesebb nyelvvizsgával a szakgimnáziumi tanulók. A 2016-os adatok ennek ellenkezőjét mutatják. Az A-típusú középfokú nyelvvizsgán kívül az összes szintü és fajtájú nyelvtudást igazoló bizonyítvány meglétét befolyásolja az, hogy milyen típusú intézménybe járt a tanuló.

A szakirodalom alapján lemorzsolódási kockázatot jelenthet, ha a hallgatót nem abba az intézménybe veszik fel, ahová elsőként jelentkezett, ezért megvizsgáltam, hogy a felvételt nyert diákokat hányadik helyre vették fel. Az eredményeket a 4. ábra szemlélteti. 


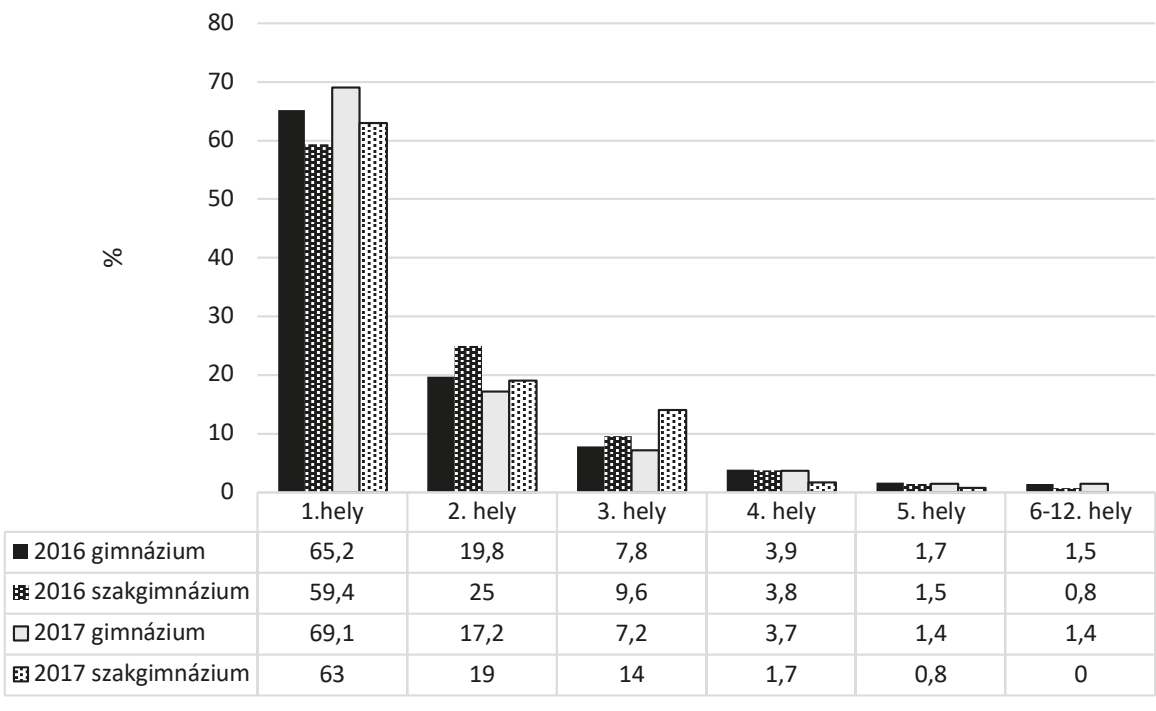

4. ábra. Hányadik helyen megjelölt intézménybe nyert felvételt a hallgató (\%) (Forrás: felvételi adatbázis; saját szerkesztés)

Az ábrán jól látható, és a statisztikai próbák $\left(\chi_{2016}^{2}=15,273 ; \mathrm{p}=0,06 ; \chi_{2017}^{2}=13,0 ; \mathrm{p}=0,224\right)$ is megerösítik, hogy nem függ a középiskola típusától az, hogy a jelentkezőt hányadik helyen jelölt intézménybe vették fel.

A kedvezőtlen anyagi háttér befolyással bír a hallgatók jólétét és jóllétét illetően a felsőoktatási intézményekben. A költségtérítés megfizetésének terhe gondot jelenthet a hallgatóknak, a hallgatók családjának. Az adatbázis nem tartalmaz a család szocioökonómiai hátterére vonatkozó információkat, így nem tudható, hogy a költségtérítéses képzésre való bejutás jelent-e az adott hallgató számára lemorzsolódási rizikófaktort. 2016-ban a gimnazistáknak a 81\%-a, 2017-ben 64\%-a, míg a szakgimnazisták 79\%-a és 2017-ben a 40\%-a jutott be államilag finanszírozott képzésre. Arányában nincs különbség a középiskola típusa és a felvételt nyert finanszírozási forma között egyik évben sem $\left(\chi^{2}=1,279 ; p=0,258\right)$.

Feltételezésem szerint az, hogy milyen irányban tanulnak tovább a tanulók, erősen függ attól, hogy milyen intézménytípusba jártak középiskolába. Ennek igazolására megnéztem, hogy a gimnáziumból és szakgimnáziumból jelentkező diákok milyen képzési területekre nyertek felvételt (5-6. ábra). 


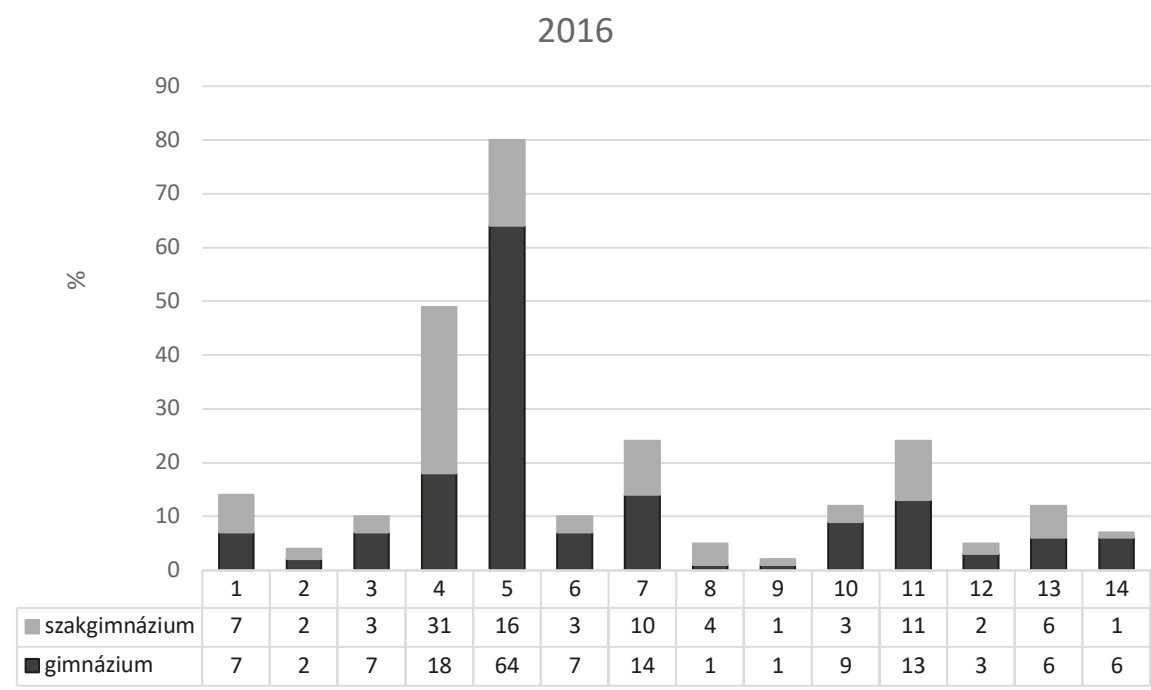

1.Agrár; 2. Közigazgatás; 3. Bölcsésztudomány; 4. Gazdaságtudomány; 5. Informatika; 6. Jog; 7. Müszaki;

8. Mủvészet; 9. Múvészetközvetítés; 10. Orvos- és Egészségtudomány; 11. Pedagógia; 12. Sport;

13. Társadalomtudomány; 14. Természettudomány

5. ábra. 2016-ban felvett hallgatók szakterületi megoszlása (forrás: felvételi adatbázis; saját szerkesztés)

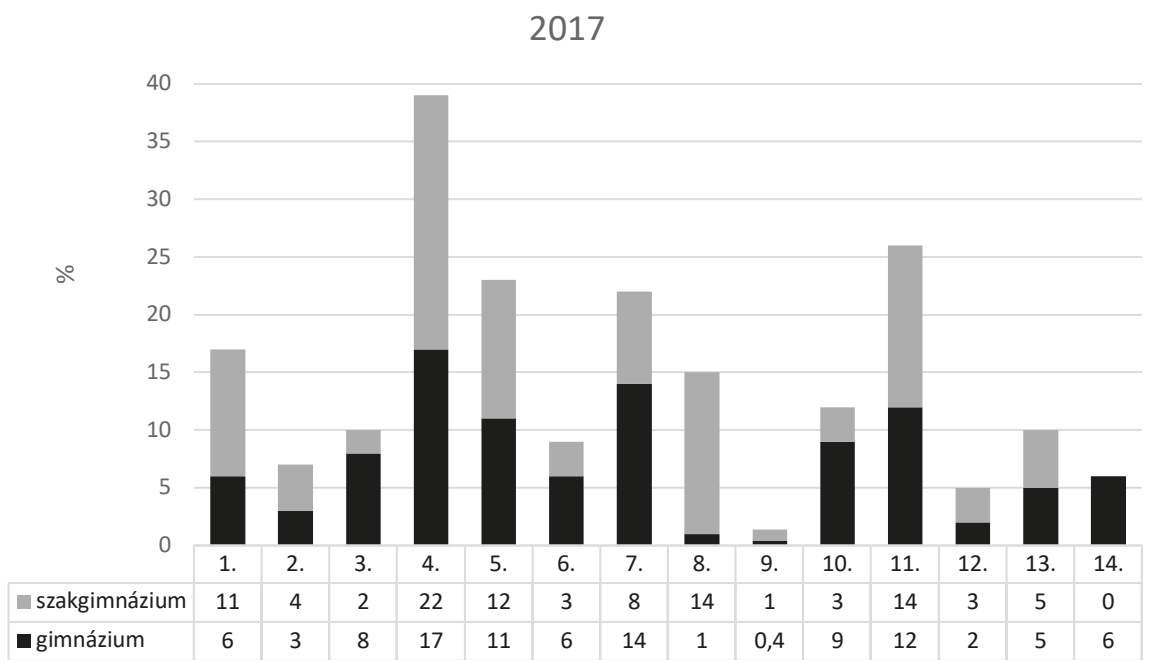

1.Agrár; 2. Államtudomány; 3. Bölcsésztudomány; 4. Gazdaságtudomány; 5. Informatika; 6. Jog; 7. Müszaki;

8. Művészet; 9. Művészetközvetítés; 10. Orvos- és Egészségtudomány; 11. Pedagógia; 12. Sport;

13. Társadalomtudomány; 14. Természettudomány

6. ábra. 2017-ben felvett hallgatók szakterületi megoszlása (forrás: felvételi adatbázis; saját szerkesztés) 
Mindkét évben a gazdaságtudományba és az informatikai szakokra jelentkeztek a legnagyobb arányban a gimnazisták és a szakgimnazisták is. 2017-ben a müszaki és pedagógusszakok területei is népszerüek voltak a diákok körében. Ezen felül az is szembetünő a diagramokon, hogy a természet-, bölcsészettudományi, jogi és orvosi képzésekre elsősorban a gimnáziumból jelentkezettek nyertek felvételt, míg a szakgimnazisták leginkább a mủvészeti pályához kapcsolódó szakokra.

Megvizsgáltam, hogy van-e különbség a felvett gimnazisták és a szakgimnazisták között a felvételi eljárás során elért összpontszámban. Mindkét év vizsgálata azt mutatja, hogy szignifikáns különbség van a részminták összpontszámainak átlagában (3. táblázat).

3. táblázat. A felvételi eljárásban szerzett pontszámok átlaga és szórása

\begin{tabular}{|l|c|c|c|c|}
\hline & Gimnázium & Szakgimnázium & \multirow{2}{*}{$\mathrm{F}(\mathrm{p})$} & \multirow{2}{*}{$\mathrm{t}(\mathrm{p})$} \\
\cline { 2 - 3 } & átlag (szórás) & átlag (szórás) & & \\
\hline 2016 & $377,22(54,961)$ & $341,16(48,191)$ & $30,883(0,001)$ & $16,594(0,001)$ \\
\hline 2017 & $382,65(53,025)$ & $349,175(52,175)$ & $0,044(0,834)$ & $6,844(0,001)$ \\
\hline
\end{tabular}

A 2016-os és 2017-es adatbázis összeillesztésével is megvizsgáltam a középiskolai intézménytípusok befolyásoló hatását az összpontszámra. Az eredmények alapján a gimnazisták $(\mathrm{t}=16,584 ; \mathrm{p}=0,001)$ szignifikánsabb magasabb pontszámot szereztek a felvételi eljárás során.

Az összefüggések mélyebb feltárása érdekében megnéztem az adatbázisban szereplő változók (középiskola típusa, külön-külön a közép- és felsőfokú nyelvvizsgák fajtáit, illetve azokat a változókat, amelyekért többletpontot lehet szerezi, mint például emelt érettségi stb.) magyarázó erejét a felvételi eljárás során elért összpontszámra. Az eredmények alapján az emelt érettségi vizsgá(k)ért kapott pluszpontok 35\%-ban magyarázzák ( $\mathrm{F}=1924,226 ; \mathrm{p}=0,001)$ az összpontszámot. Az elemzésbe bevont többi független változó is szignifikáns magyarázóerővel bír a tanulók által elért összpontszám különbségeiben. A felsőfokú C-típusú nyelvvizsga $(\mathrm{F}=245,307$; $\mathrm{p}=0,001)$ 4\%-ban magyarázza az összpontszámot, míg a nyelvvizsgákért $(\mathrm{F}=121,380 ; \mathrm{p}=0,001)$ és a felsőfokú szakképzésért $(\mathrm{F}=127,341 ; \mathrm{p}=0,001)$ kapott pluszpontok 2-2\%-os szignifikáns magyarázóerővel bírnak. A többi független változók, melyben a nyelvvizsga-típusok, a sportért kapott többletpont és a középiskola típusa van benne, együttes magyarázóereje 3,5\%.

\section{Összegzés}

Az utóbbi évtizedekben egyre nagyobb hangsúlyt kap a lemorzsolódás jelenségének feltárása az oktatás minden szintjén. A felsőoktatásban elsősorban a demokratizálódás következtében jelentkező expanzió és tömegesedés okaként ütötte fel a fejét. Egyértelmüen nem kijelenthető, hogy egy egyetemre, karra nézve ez negatív jelenség, hiszen okozhatja a képzés magas színvonalú jellege is a magasabb lemorzsolódási arányt (Polónyi, 2017). Munkámban nem erre, hanem a hallgatóra, intézményre és a társadalomra nézve problémát jelentő lemorzsolódásra helyeztem a hangsúlyt.

Dolgozatom első részében a felsőoktatásból való kimaradás, lemorzsolódás hátterét, jelenségét és a szakirodalom alapján eddig feltárt magyarázó tényezőket vettem sorra. Munkám második részében arra kerestem a választ, hogy a szakirodalom által feltárt okok közül melyek azonosíthatóak már a felsőoktatásba való jelentkezéskor. Továbbá azt vizsgáltam, hogy a szakgimnáziumból érkező tanulók a felvételi eljárás folyamatában eltérnek-e, és ha igen, akkor miben, a gimnazistákhoz képest. 
Kutatásomban a 2016-os és 2017-es felvételi adatbázisok Dél-Alföld régiójában található középiskolák gimnáziumaiból és szakgimnáziumaiból az adott évben érettségizett felvételizőket vizsgáltam. Mivel az adatbázis csak néhány szociodemográfiai adatot tartalmaz, ezért az affektív és szociális, illetve szocioökonómiai faktorokat nem tudjuk belőle elemezni. Ezek feltárására interjú vagy kérdőíves vizsgálati módszer alkalmazása szükséges.

Elsőként arra kerestem a választ, hogy a felsőoktatásba való jelentkezés előtt és a jelentkezés benyújtásakor milyen lemorzsolódási rizikófaktorok azonosíthatók, és milyen különbségek vannak a gimnáziumból és szakgimnáziumból továbbtanulni szándékozók között. Az adatbázisok elemzése során azt találtam, hogy szignifikáns különbséget jelent a felvettek körében az, hogy milyen iskolatípusból jelentkeznek a felsőoktatásba. A gimnáziumokból nagyobb arányban mennek továbbtanulni a diákok, mint szakgimnáziumból.

Magyarországon a diplomaszerzés egyik kritériuma, hogy a hallgatónak rendelkeznie kell legalább egy középfokú C-típusú nyelvA szakirodalom alapján lemorzsolódási rizikófaktort jelenthet,

ha a hallgatót nem arra a képzésre veszik fel, amire elsóként jelentkezett, ezért megvizsgáltam, hogy a felvett tanulók milyen arányban kerültek be az elsó helyen megjelölt szakra.

Mindkét évben mindkét típusú középiskolából jelentkezó diákoknak több mint 60\%-át felvették az elsố helyre. A vizsgált minta 40\%-ánál kevesebb hallgatónál jelentkezhetnek az intézményi és saját tulajdonságok közötti nem megfeleló illeszkedések, más elvárások, melyek a felsóoktatási intézmény elhagyásához vezethetnek. vizsga-bizonyítvánnyal. Ennek hiánya közismerten oka annak, hogy a diákok diploma nélkül hagyják el a felsőoktatást, ezért megnéztem, hogy a felvettek közül hogyan alakul a nyelvtudást igazoló bizonyítvány megléte a gimnazisták és szakgimnazisták körében. A kapott eredmények ellentmondásosak, a két adatbázis mást mutat: a 2016-os adatok szerint befolyásolja a nyelvvizsga-bizonyítvány meglétét az iskolatípus, míg a 2017-es adatbázisnál ennek ellenkezöjét kaptam. Annak kiderítésére, hogy befolyásolja-e a közoktatási intézménytípus a nyelvtudást igazoló okmány meglétét, további, országos vizsgálatok szükségesek.

A szakirodalom alapján lemorzsolódási rizikófaktort jelenthet, ha a hallgatót nem arra a képzésre veszik fel, amire elsőként jelentkezett, ezért megvizsgáltam, hogy a felvett tanulók milyen arányban kerültek be az első helyen megjelölt szakra. Mindkét évben mindkét típusú középiskolából jelentkező diákoknak több mint 60\%-át felvették az első helyre. A vizsgált minta 40\%-ánál kevesebb hallgatónál jelentkezhetnek az intézményi és saját tulajdonságok közötti nem megfelelő illeszkedések, más elvárások, melyek a felsőoktatási intézmény elhagyásához vezethetnek.

Az iskolaelhagyás kockázati tényezői közé tartozik az anyagi nehézség is, melynek egyik szála a költségtérítés terhe. Mivel az adatbázisokból csak a költségtérítéses képzésre való felvétel derül ki és a felvett hallgatók gazdasági háttere nem, így egyértelmü következtetés nem vonható le a lemorzsolódást tekintve.

Második kutatási kérdésemmel kapcsolatban azt feltételeztem, hogy a gimnáziumból és szakgimnáziumból jelentkezők közötti különbség a szakok iránti érdeklődésben is megmutatkozik. Az elemzés eredményei azt mutatják, hogy a természet-, orvos-, jogi és bölcsésztudományi karokon a gimnáziumból továbbtanuló, míg a művészeti és - elsősorban a 2017-es adatok alapján - az agrárképzéseken a szakgimnazista diákok vannak 
többségben. Az informatika, pedagógus és gazdaságtudományi szakok mind a gimnazisták, mind a szakgimnazisták körében népszerüek. Mivel ezek a képzések széles kínálattal rendelkeznek, ezért alaposabb elemzésre van szükség ahhoz, hogy meg lehessen határozni, hogy melyik intézmény milyen szakjára és hány ponttal kerülnek be a gimnazisták és szakgimnazisták.

Utolsó kutatási kérdésként arra kerestem a választ, hogy a felvételi során elért összpontszámot mi határozza meg leginkább. A felvételi eljárásban többletpontok szerezhetők, ezek közül az emelt érettségire kapott pluszpontok magyarázzák legnagyobb mértékben a felvételi összpontszámát. A tíz bevont független változók közül az iskolatípus rendelkezik a legkisebb magyarázóerővel.

A vizsgálat eredményei alapján elmondható, hogy már a jelentkezés pillanatában azonosíthatók olyan rizikófaktorok, melyek később a felsőoktatási tanulmányok idő előtti, diplomaszerzés nélküli elhagyásához vezethetnek. A középiskola típusának befolyása a felvételi sikerességére és az azonosított kockázati tényezőkre nem mutat egységes mintázatot. A kutatás korlátai között említendő, hogy csak két éves időszak adatbázisát elemeztem egy régióra koncentrálva, továbbá kihagytam a mintából a többcélú intézmények tanulót a nem egyértelmű iskolatípus beazonosítása miatt. Mindez limitálja az eredmények általánosíthatóságát. További, szélesebb körü vizsgálatok szükségesek a kapott adatok finomítása érdekében, illetve célszerü lenne az adatbázisok elemzését kérdőíves vizsgálattal vagy interjúval kiegészíteni, mely tovább bővítheti tudásunkat a lemorzsolódás okairól és a középiskola típusának hatásáról.

\section{Irodalom}

Astin, A. W. (1993). What Matters in College: Four Critical Years Revisited. San Francisco, CA: Jossey-Bass.

Berde Éva (2013). A felsőoktatás lehetséges létszámpályái Magyarországon. Statisztikai Szemle, 91(1), 57-76.

Bean, J. P. (1981). The synthesis of a theoretical model of student attrition. https://files.eric.ed.gov/ fulltext/ED202444.pdf Utolsó letöltés: 2018. 12. 23.

Bean, J. P. (1980). Dropouts and turnover: The synthesis and test of a causal model ofstudent attrition. Research in Higher Education, 12(2), 155-187. DOI: 10.1007/BF00976194

Bean, J. \& Metzner, B. (1985). A Conceptual Model of Nontraditional Undergraduate Student Attrition. Review of Educational Research, 55(4), 485-540. DOI: 10.3102/00346543055004485

Berge, Z. L. \& Huang, Y. P. (2004). A Model for Sustainable Student Retention: A Holistic Perspective on the Student Dropout Problem with Special Attention to e-Learning. DEOSNEWS, 13(5).

Bornstein, M. H. (2015). Children's parents. In Lerner, R., Bornstein, M. \& Leventhal, T. (szerk.), Handbook of child psychology and developmental science. Volume 4, Ecological settings and processes, Chapter 3. Hoboken, NJ: Wiley. 1-78. DOI: 10.1002/9781118963418.childpsy403
Cabrera, A. F., Nora, A. \& Castañeda, M. B. (1993). College Persistence. Structural Equations Modeling Test of an Integrated Model of Student Retention. Journal of Higher Education, 64(2), 123-139. DOI: $10.2307 / 2960026$

Cabrera, L., Tomás, J. T., Álvarez, P. \& Gonzalez, M. (2006). The Problem of University Dropout. Relieve, 12(2), 171-203. https://www.uv.es/RELIEVE/v12n2/ RELIEVEv12n2_1eng.pdf Utolsó letöltés: 2018. 12. 26.

Cardoso, S. \& Tavares, O. (2018). Students' Drop Out, Higher Education. In Teixeira, P. \& Shin, J. (szerk.), Encyclopedia of International Higher Education Systems and Institutions. Dordrecht: Springer. 1-3. DOI: 10.1007/978-94-017-9553-1 432-1

Csanády Márton (2005). Újhullámok az európai felsőoktatásban Az Európai Unió új tagországainak és tagjelöltjeinek felsőoktatási folyamatai. Iskolakultúra, 15(5), 61-78.

Derényi András (2015). Bizonyítékokra alapozott kormányzás és a kommunikáció képzés. Jel-Kép, 12-34. DOI: 10.20520/Jel-Kep.2015.1.KLSZ.21

Duncan, G. J., Magnuson, K. \& Votruba-Drzal, E. (2015). Children and socioeconomic status. In Lerner, R. M., Bornstein, M. \& Leventhal, T. (szerk.), Handbook of child psychology and developmental science. Volume 4, Ecological settings and processes, Chapter 14. Hoboken, NJ: Wiley. 1-40. DOI: 10.1002/9781118963418.childpsy414 
Engler Ágnes (2017). A család mint eröforrás. Budapest: Gondolat Kiadó.

Engler Ágnes (2015). Családstruktúra és eredményesség. In Pusztai Gabriella \& Kovács Klára (szerk.), Ki eredményes a felsőoktatásban? (Nagyvárad-Budapest: Partium Könyvkiadó - Personal Problems Solution - Új Mandátum Könyvkiadó. 152-160.

Fehérvári Anikó (2015). Lemorzsolódás és a korai iskolaelhagyás trendjei. Neveléstudomány, 3. 31-47.

Fehérvári Anikó (2008, szerk.). Szakképzés és lemorzsolódás. Kutatás közben 283. Budapest: Oktatáskutató és Fejlesztő Intézet.

Fenyves V., Bácsné Bába É., Szabóné Szőke R., Kocsis I., Juhász Cs., Máté E. \& Pusztai G. (2017). Kísérlet a lemorzsolódás mértékének és okainak megragadására a Debreceni Egyetem Gazdaságtudományi Kar példáján. Neveléstudomány, 3. 5-14. DOI: 10.21549/NTNY.19.2017.3.1

Gáti A. \& Róbert P. (2011). Munkavállalás a tanulás mellett: kényszerüség vagy befektetés? In: Garai O. és Veroszta Zs. (szerk.), Frissdiplomások. Budapest: Educatio Társadalmi Szolgáltató Nonprofit Kft. 93-111.

Gazsó Ferenc (1997). A társadalmi folyamatok és a felsőoktatás. Eszmélet, 35(3), 1-9.

Gilmore, L., Islam, S., Younesian, S., Bús, E. \& Józsa, K. (2017). Mastery motivation of university students in Australia, Hungary, Bangladesh and Iran. Hungarian Educational Research Journal, 7(2), 178-191. DOI: 10.14413/HERJ/7/2/11

Horn, L. J. (1998). Stopouts or Stayouts? Undergraduates Who Leave College in Their First Year. U.S. Department of Education, National Center for Education Statistics, 1999, 087.

Hrubos Ildikó (1999). A felsőoktatás dilemmái a tömegessé válás korszakában. Budapest: Oktatáskutató Intézet.

Hrubos Ildikó (2014). Expanzió - határok nélkül. Educatio, 24(2), 205-215.

Kozma Tamás (2010). Expanzió. (Mérleg 2006-2010) Educatio, 19(1), 7-18.

Kozma Tamás (2004). Kié az egyetem? A felsőoktatás nevelésszociológiája. Budapest: Új Mandátum Kiadó.

Ladányi Sándor (1999). A magyar felsőoktatás a 20. században. Budapest: Akadémiai Kiadó.

Lukács Fruzsina \& Sebő Tamás (2015). Az egyetemi lemorzsolódás kérdőíves vizsgálata. Iskolakultúra, 25(10), 78-86. DOI: 10.17543/ISKKULT.2015.10.78

Macqueen, S. (2017). Narratives from non-traditional students in higher education. The thesis is submitted for the degree of Doctor of Philosophy at The University of Queensland in 2017. University of Queensland. DOI: 10.14264/uql.2018.141
Miskolci Péter, Bársony Fanni \& Király Gábor (2018). Hallgatói lemorzsolódás a felsőoktatásban: elméleti, magyarázati utak és kutatási eredmények összefoglalása. Iskolakultúra, (28)3-4, 87-105. DOI: 10.17543/ISKKULT.2018.3-4.3

Molnár Beáta (2012). A felsőoktatásban tapasztalható lemorzsolódás csökkentése innovatív módszerekkel. In Buda A. \& Kiss E. (szerk.), Interdiszciplináris pedagógia és a felsőoktatás alakváltozásai. A VII. Kiss Árpád emlékkonferencia elöadásainak szerkesztett változata. Kiss Árpád Archivum Könyvsorozata. Debrecen: Debreceni Egyetem Neveléstudományok Intézete. 350-357.

Molnár Pál \& Pintér Henriett (2018). Az együttműködés iránti attitüd hatása a közös tanulás és a közösséghez tartozás észlelésére kutatásalapú tanulásban részt vett tanulók körében. Magyar Pedagógia, 118(1), 3-26. DOI: 10.17670/MPed.2018.1.3

Nagy Péter Tamás (2003). A felsőoktatásba vezető út - és a társadalmi hátrányok kompenzációja. Educatio, 12(3), 236-252.

Organisation for Economic Co-operation and Development. (2009). Education at a glance. OECD indicators. http://www.oecd.org/dataoecd/41/25/43636332. pdf Utolsó letöltés: 2018. 12. 19.

Price, J. (2006): Does a Spouse Slow You Down? Marrige and Graduate Student Outcomes. Ithaca, Cornell University. DOI: 10.2139/ssrn.933674

Polónyi István (2018). A hazai felsőoktatás felvételi tendenciái és hallgatólétszámának néhány jellemzője. In Kováts Gergely \& Temesi József (szerk.), A magyar felsőoktatás egy évtizede 2008-2017. Budapest: Budapesti Corvinus Egyetem NFKK. 111-129.

Polónyi István (2017). Az oktatáspolitika müveltségképe. Neveléstudomány, 1, 5-14. DOI: 10.21549/ NTNY.17.2017.1.1

Polónyi István (2014). Régi, új felsőoktatási expanzió. Educatio, 27(2), 1-21.

Polónyi István (2012). Honnan jönnek a hallgatók? Educatio, 24(2), 1-15.

Polónyi István (2006). A munkaerőpiacra orientált felsőoktatási minőségbiztosítás. In. Bálint J., Polónyi I. \& Siklós B. (szerk.), A felsöoktatás minősége. Budapest: Felsőoktatási Kutatóintézet. 10-38.

Pukánszky Béla (2013). A nőnevelés története. Gondolat Kiadó, Budapest

Pusztai Gabriella (2015). Tanulmányi eredményességet támogató tényezők az egyetem falain belül és kívül. In Pusztai Gabriella \& Kovács Klára (szerk.), Ki eredményes a felsőoktatásban? Nagyvárad-Budapest: Partium Könyvkiadó - Personal Problems Solution - Új Mandátum Könyvkiadó. 79-96.

Pusztai Gabriella (2011). A láthatatlan kéztöl a baráti kézig. Hallgatói értelmezői közösségek. Budapest: Új Mandátum Kiadó. 
Józsa Gabriella: Lemorzsolódási rizikófaktorok a felvételi adatbázis alapján

Rausch, J. L. \& Hamilton, M. W. (2006). Goals and Distractions: Explanations of Early Attrition from Traditional University Freshmen. The Qualitative Report, 11(2), 317-334. Retrieved from https://nsuworks.nova. edu/tqr/vol11/iss2/6 Utolsó letöltés: 2018. 12. 26.

Sáska Géza (2014): Húsz év köz- és felsőoktatásáról, körkép. Iskolakultúra, 24(2), 3-18.

Szemerszki Mariann (2014). A középiskolából a felsőoktatásba. Jelentkezési és felvételi tendenciák. Felsöoktatási Mühely, 1. 47-63.

Temesi József (2016). A magyar felsőoktatás változásai 1988 és 2014 között: trendelemzések elökészítése a szakirodalom alapján. In Derényi A. \& Temesi J. (szerk), A magyar felsöoktatás 1988 és 2014 között. Oktatáskutató és Fejlesztő Intézet, Budapest. 53-80.

Tinto, V. (1975). Dropout from higher education: A theoretical synthesis of recent literature. A Review of Educational Research, 45, 89-125. DOI: 10.3102/00346543045001089

Tinto, V. (1993). Leaving college: Rethinking the causes and cures of student attrition (2nd ed.). Chicago and London: The University of Chicago Press. DOI: 10.7208/chicago/9780226922461.001.0001

Trow, Martin (1974). Problems in the transition from elite to mass higher education. Policies for Higher Education. Paris: OECD. https://files.eric.ed.gov/ fulltext/ED091983.pdf

Tyler, J. H. \& Lofstrom, M. (2009). Finishing high school: alternative pathways and dropout recovery. Future of Children, 19(1) 77-103. DOI: 10.1353/ foc. 0.0019

Ugrai János (2012). A felsőoktatási és a felsőoktatás-politikai környezet változásai a miskolci bölcsészkar kapcsán. In Illésné Kovács M. (szerk.), Docēre et movère - Bölcsészet- és társadalomtudományi tanulmányok a Miskolci Egyetem Bölcsészettudományi Kar 20 éves jubileumára. Miskolc: ME BTK. 15-19.

Veroszta Zsuzsanna (2010). A felsőoktatás társadalmi felelössége a hallgatói értékkészletekben. Educatio, (19) 2, 230-240.

\begin{abstract}
Absztrakt
A felsőoktatás átalakulásával a hallgatói társadalom is átalakult. Az eddig szük rekrutációs bázisra épülő egyetemek kapui széles társadalmi rétegek számára nyíltak meg. A hallgatói összetétel heterogenitásával megjelent a lemorzsolódás jelensége, ami nem csak a felsőoktatást és Magyarországot érinti, hanem a közoktatást és szinte az egész világot. Számos szerző hangsúlyozza az első egyetemi év jelentőségét (Horn, 1998), hiszen ekkor szocializálódik az egyén az egyetem világába, alakítja ki kapcsolatait a hallgatótársakkal, az oktatókkal és az intézmény egészével (Pusztai, 2011). Továbbá ekkor derülnek ki, hogy a meglévő tanulási módszerek, képességek és anyagi ráfordítások milyen mértékben elegendőek a bennmaradáshoz. Munkámban arra keresem a választ, hogy a továbbtanulás előtt álló középfokú szakképzésbe járó hallgatók körében milyen korai lemorzsolódáshoz vezető kockázati faktorok azonosíthatók, és ezek mennyiben különböznek a gimnáziumból jelentkezőktől. A 2016-os és 2017-es felvételi adatbázisok Dél-Alföld régiójában található középiskolákból jelentkező tanulókat vizsgáltam. Az eredmények azt mutatják, hogy nem minden rizikófaktor tekintetében lehet egyértelmủen beazonosítani az intézményi különbséget.
\end{abstract}

